\title{
Proposal of a New Method for Differentiating Races of Pyricularia oryzae Cavara in Japan
}

\author{
Masao Yamada*, Shigehisa Kiyosawa**, Tomio Yamaguchi***, \\ Tetsuya Hirano****, Takashi Kobayashi*****, Kinya Kushibuchi*, \\ and Shinji WATANABE $* * * * * *$ (The committee for a new method \\ to differentiate rice blast races)
}

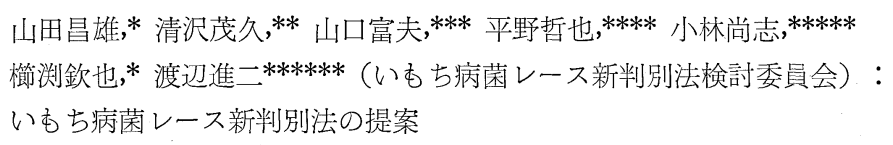

Many reports have been published in Japan on the pathogenic specialization of rice blast fungus, Pyricularia oryzae. Especially, Goto and his co-workers ${ }^{1}$, 2) have established the method to identify blast fungus races.

Their differential varieties consist of 12 varieties belonging to the following 3 groups.

$\mathrm{T}$ group (varieties having rice blast resistance genes of indica rice)

Te-tep, Tadukan, and Usen

$\mathrm{C}$ group (varieties having resistance genes of Chinese varieties)

Chokoto, Yakeiko, and Kanto 51

$\mathrm{N}$ group (other common Japanese varieties)

Ishikari-shiroke, Homare-nishiki, Ginga, Norin 22, Aichi-asahi, and Norin 20

According to their method, blast fungus isolates found in Japan are classified into $\mathrm{N}, \mathrm{C}$, and $\mathrm{T}$ groups. $\mathrm{N}$ group races are defined as the races virulent only to $\mathrm{N}$ (Japanese) varieties in the differentials. $\mathrm{C}$ group races are virulent to $\mathrm{C}$ (Chinese), but not to $\mathrm{T}$ varieties in the differentials, irrespective of the virulence to $\mathrm{N}$ varieties. $\mathrm{T}$ group races are virulent to $\mathrm{T}$ (indica) varieties, irrespective of the virulence to $\mathrm{C}$ and $\mathrm{N}$ differentials. Then each race is numbered in the order of the identification in each race group, such as $\mathrm{T}-1$ or $\mathrm{C}-3$. With this procedure, 3 races of $\mathrm{T}, 9$ races of $\mathrm{C}$, and 6 races of $\mathrm{N}$ race group have been differentiated until now.

This procedure was adopted widely in Japan, and the situation of pathogenic specialization of rice blast fungus in Japan has been clarified ${ }^{1-3}$.

\footnotetext{
* Central Agricultural Experiment Station, Konosu, Saitama, Japan. 農事試験場

** Division of Genetics, National Institute of Agricultural Sciences, Hiratsuka, Kanagawa, Japan. 農業技術研究所遺伝科

*** Division of plant Pathology, National Institute of Agricultural Sciences, Nishigahara,

Tokyo, Japan. 農業技術研究所病理科

**** Akita Prefectural College of Agriculture, Ogata, Akita, Japan. 秋田農業短期大学

***** Tropical Agriculture Research Center, Yatabe, Ibaraki, Japan. 熱帯農業研究センター

******Tohoku National Agricultural Experiment Station, Omagari, Akita, Japan. 東北農業試験場

1) Goto, K. et al. (1961). Plant disease and insect forecasting service Spec. Bull. 5, 89p.

(in Japanese) 2) Goto, K. et al. (1964). ibid. 18, 132p. (in Japanese) 3) Kozaka, T. et al. (1972). ibid. 24, 296p. (in Japanese)
} 
Kiyosawa and his co-workers conducted genetic studies on blast resistance of rice varieties on the basis of the results of race studies ${ }^{4)}$. In the course of their studies, it has been clarified that Goto and his co-workers' differential varieties are not always best ${ }^{5-7)}$. Sakurai and Toriyama ${ }^{6}$ pointed out the defects of these differentials as follows:

(1) Some important resistance genes are not included in these differentials.

(2) Some differential varieties are very complicated with respect to resistance gene constitutions.

(3) Some differential varieties have some unknown resistance genes, not included in Japanese commercial varieties.

(4) Some differential varieties have the same resistance genes.

A committee was organized and discussed a new set of differentials and new nomenclature of races. After reviewing many workers' opinions and results of inoculation tests, the committee presents the following proposal.

\section{Selection of new differential varieties}

Selection of varieties was made according to the following criteria presented by Sakurai and Toriyama ${ }^{6}$.

(1) Each differential variety should have only one major true resistance gene which is effective to Japanese blast fungus races and is included in commercial varieties in Japan. These genes are desired to be confirmed by genetic analysis.

(2) The differential varieties should be genetically pure, and their reactions against blast races should be stable.

(3) The differential varieties should be of common japonica type, and their cultivation and seed collection should be easy, even though they are derived from foreign varieties.

(4) The present standard and supplemental differential varieties should be included as far as possible.

The committee adopted the following 9 varieties which have singly different genes for true resistance according to the above-mentioned criteria.

$P i-k^{s}:$ Shin $2^{8)} \quad P i-a$ : Aichi-asahi ${ }^{9)} \quad P i-i$ : Ishikari-shiroke ${ }^{10)}$

$P i-k$ : Kanto 51 ${ }^{10)} P i-m$ : Tsuyuake ${ }^{11)} P i-z$ : Fukunishiki12)

$P i-t a$ : Yashiro-mochi ${ }^{13)} P i-t a^{2}:$ Pi No. $4^{13)} P i-z^{t}$ : Toride $1^{14)}$

Shin 2 is susceptible to all Japanese blast races, but has a blast resistance gene $P i-k^{s}$, which is active against a Philippine blast isolate Ken $\mathrm{Ph}-03^{8)}$, and not active against Japanese races. There are 2 kinds in Shin 2 type varieties. One has $P i-k^{s}$ and the other does not. Shin 2 belongs to the former. $P i-m$ gene was identified in variety Minehikari by Kiyosawa ${ }^{15)}$. Minehikari has $P i-a$ and $P i-k$ genes besides $P i-m^{15}$, and Tsuyuake has $P i-k$ gene besides $P i-m^{11)}$. Tsuyuake was adopted temporarily as a differential variety for $P i-m$, but it should be replaced

4) Kiyosawa, S. (1974). Misc. Publ. Natl. Inst. Agric. Sci., Ser. D. 1 : 1-58. (in Japanese)

5) - - (1972). Japan. J. Breed. 22 : 119-123. (in Japanese) 6) Sakurai, Y. and Toriyama,

K. (1973). Kenkyu Seika (The results of researches) Agriculture, Forestry and Fisheries Research Council, Ministry of Agriculture and Forestry, Tokyo. 63:86-88. (in Japanese)

7) Asaga, K. (1974). Nogyo Gijutsu 29:443-448. (in Japanese) 8) Kiyosawa, S. (1969). Japan. J. Breed. 19:61-73. 9) Kiyosawa, S. et al. (1967). ibid. 17:1-6 10) Yamasaki, Y. and Kiyosawa, S. (1966). Bull. Natl. Inst. Agric. Sci., Ser. D. 14: 39-6气. (in Japanese)

11) Ezuka, A. et al. (1969). Bull. Chugoku Agr. Exp. Sta., Ser. E. 4 : 1-31. (in Japanese)

12) Kiyosawa, S. (1967). Japan. J. Breed. 17:99-107. 13) -(1969). Agr. Hort.

44:407-408. (in Japanese) 14) Yokoo, M. and Kiyosawa, S. (1970). Japan. J. Breed.

$20: 129-132$. 15) Kiyosawa, S. (1968). Japan. J. Breed. $18: 193-205$. 
in future by another variety having $P i-m$ solely.

\section{New nomenclature of the races}

When a new set of differentials is adopted, the name of races should also be changed. If the races are numbered in the order of their discovery, the number will become very large, and it will be very difficult to understand virulence of races from their numbers. When some new resistance genes are introduced in future, some new differential varieties having them should be supplemented. Under such consideration, the committee adopted Gilmour's octal notation ${ }^{16)}$ according to Asaga's proposal $^{7)}$.

First, 9 differential varieties are arranged in the order listed in Table 1, and code number is given to each resistance gene, and to each corresponding differential variety, as shown in Table 1 . Code number 20 is for $P i-m$. It is also for Tsuyuake having $P i-m$ and $P i-k$ genes, because we have no variety having $P i-m$ solely at present. The number of each race is the sum of code number of each resistance gene, accordingly of each differential variety, to which the race is virulent. For example, the race virulent only to Shin $2\left(P i-k^{s}\right)$ is 1 , and the race virulent to Shin 2, Aichi-asahi $(P i-a)$, and Ishikari-shiroke $(P i-i)$ is $1+2+4=7$. Furthermore, the race virulent to Fukunishiki $(P i-z)$, Yashiro-mochi $(P i-t a)$, and Pi No. $4\left(P i-t a^{2}\right)$,

Table 1. The reaction of some isolates on the new differential varieties

\begin{tabular}{|c|c|c|c|c|c|c|c|c|c|c|c|}
\hline $\begin{array}{c}\text { Differential } \\
\text { varieties }\end{array}$ & Shin 2 & $\begin{array}{l}\text { ichi- } \\
\text { sahi }\end{array}$ & $\begin{array}{l}\text { hikari- } \\
\text { hiroke }\end{array}$ & $\begin{array}{c}\text { Kan to } \\
51\end{array}$ & $\begin{array}{c}\text { Tsuyu- } \\
\text { ake }\end{array}$ & $\begin{array}{l}\text { Fuku- } \\
\text { nishiki }\end{array}$ & $\begin{array}{r}\text { Yashir } \\
\text { moch }\end{array}$ & Pi N0.4 & $\begin{array}{c}\text { Toride } \\
1 \\
\end{array}$ & \multirow{2}{*}{\multicolumn{2}{|c|}{$\begin{array}{l}\text { Current } \\
\text { race } \\
\text { number }\end{array}$}} \\
\hline $\begin{array}{l}\text { Resistance } \\
\text { gene }\end{array}$ & $P i-k^{s}$ & $P i-a$ & $P i-i$ & $P i-k$ & $P i-m$ & $P i-z$ & \multicolumn{3}{|c|}{$P i-t a P i-t a^{2} P i-z^{t}$} & & \\
\hline $\begin{array}{l}\text { Code number } \\
\text { Isolate }\end{array}$ & 1 & 2 & 4 & 10 & 20 & 40 & 100 & 200 & 400 & \multicolumn{2}{|c|}{$\begin{array}{l}\text { New } \\
\text { race } \\
\text { number }\end{array}$} \\
\hline Ken $53-33$ & $\mathrm{~S}$ & $\mathrm{~S}$ & $\mathrm{~S}$ & $\mathrm{~S}$ & $\mathrm{~S}$ & $\mathrm{R}$ & $\mathrm{S}$ & $\mathbf{R}$ & $\mathrm{R}$ & $\mathrm{T}-1$ & 137 \\
\hline Hiro $63-20$ & $\mathrm{~S}$ & $\mathrm{~S}$ & $\mathrm{R}$ & $\mathrm{R}$ & $\mathrm{R}$ & $\mathrm{R}$ & S & S & $\mathrm{R}$ & $\mathrm{T}-2$ & 303 \\
\hline Chu $65-673$ & $\mathrm{~S}$ & $\mathrm{~S}$ & $\mathrm{R}$ & $\mathrm{R}$ & $\mathrm{R}$ & $\mathbf{R}$ & $\mathrm{S}$ & $\mathrm{R}$ & $\mathrm{R}$ & $\mathrm{T}-2$ & 103 \\
\hline Ken $64-52$ & $\mathrm{~S}$ & $\mathrm{~S}$ & $\mathrm{~S}$ & $\mathrm{R}$ & $\mathrm{R}$ & $\mathrm{R}$ & $\mathrm{S}$ & $\mathrm{R}$ & $\mathrm{R}$ & $\mathrm{T}-3$ & 107 \\
\hline Ken $60-19$ & S & $\mathrm{S}$ & $\mathrm{S}$ & $\mathrm{S}$ & $\mathrm{S}$ & $\mathrm{R}$ & $\mathrm{R}$ & $\mathrm{R}$ & $\mathrm{R}$ & $\mathrm{C}-1$ & 037 \\
\hline Oita $65-114$ & $\mathrm{~S}$ & $\mathrm{~S}$ & $\mathrm{~S}$ & $\mathrm{~S}$ & $\mathrm{R}$ & $\mathbf{R}$ & $\mathrm{R}$ & $\mathrm{R}$ & $\mathrm{R}$ & $C-1$ & 017 \\
\hline Naga 87 & $\mathrm{~S}$ & $\mathrm{R}$ & $\mathrm{R}$ & $\mathrm{S}$ & $\mathrm{S}$ & $\mathrm{R}$ & $\mathrm{S}$ & $\mathrm{R}$ & $\mathrm{R}$ & $C-3$ & 131 \\
\hline Ina 72 & $\mathrm{~S}$ & $\mathrm{R}$ & $\mathrm{R}$ & $\mathrm{S}$ & S & $\mathrm{R}$ & $\mathrm{R}$ & $\mathrm{R}$ & $\mathrm{R}$ & $C-3$ & 031 \\
\hline Ken $61-14$ & $\mathrm{~S}$ & $\mathrm{~S}$ & $\mathrm{~S}$ & $\mathrm{~S}$ & $\mathrm{R}$ & $\mathrm{R}$ & $\mathrm{R}$ & $\mathrm{R}$ & $\mathbf{R}$ & $C-5$ & 017 \\
\hline Ken $66-25$ & $\mathrm{~S}$ & $\mathrm{~S}$ & S & $\mathrm{S}$ & $\mathrm{R}$ & $\mathrm{R}$ & $\mathrm{R}$ & $\mathrm{R}$ & $\mathrm{R}$ & $C-6$ & 017 \\
\hline Naga $64-8$ & $\mathrm{~S}$ & $\mathrm{~S}$ & $\mathrm{R}$ & S & $\mathrm{S}$ & $\mathrm{R}$ & $\mathrm{R}$ & $\mathrm{R}$ & $\mathrm{R}$ & $C-8$ & 033 \\
\hline Naga $65-386$ & $\mathrm{~S}$ & $\mathrm{R}$ & $\mathrm{S}$ & $\mathrm{S}$ & $\mathrm{S}$ & $\mathrm{R}$ & $\mathrm{R}$ & $\mathrm{R}$ & $\mathbf{R}$ & $C-9$ & 035 \\
\hline Hoku 1 & $\mathrm{~S}$ & $\mathrm{~S}$ & $\mathrm{~S}$ & $\mathrm{R}$ & $\mathrm{R}$ & $\mathrm{R}$ & $\mathrm{R}$ & $\mathrm{R}$ & $\mathbf{R}$ & $\mathrm{N}-1$ & 007 \\
\hline Ken $64-38$ & $\mathrm{~S}$ & $\mathrm{~S}$ & $\mathrm{R}$ & $\mathrm{R}$ & $\mathrm{R}$ & $\mathbf{R}$ & $\mathbf{R}$ & $\mathrm{R}$ & $\mathrm{R}$ & $\mathrm{N}-2$ & 003 \\
\hline Ken 54-04 & $\mathrm{S}$ & $\mathrm{S}$ & $\mathrm{R}$ & $\mathrm{R}$ & $\mathbf{R}$ & $\mathrm{R}$ & $\mathrm{R}$ & $\mathrm{R}$ & $\mathrm{R}$ & $\mathrm{N}-3$ & 003 \\
\hline Ina 168 & $\mathrm{~S}$ & $\mathrm{R}$ & $\mathrm{R}$ & $\mathrm{R}$ & $\mathrm{R}$ & $\mathbf{R}$ & $\mathrm{S}$ & $\mathrm{R}$ & $\mathbf{R}$ & $\mathrm{N}-4$ & 101 \\
\hline Naga $66-16$ & $\mathrm{~S}$ & $\mathrm{R}$ & $\mathrm{R}$ & $\mathrm{R}$ & $\mathrm{R}$ & $\mathrm{R}$ & $\mathrm{R}$ & $\mathrm{R}$ & $\mathrm{R}$ & $N-4$ & 001 \\
\hline Naga $61-14$ & $\mathrm{~S}$ & $\mathrm{R}$ & $\mathrm{S}$ & $\mathrm{R}$ & $\mathrm{R}$ & $\mathrm{R}$ & $\mathrm{R}$ & $\mathrm{R}$ & $\mathrm{R}$ & $\mathrm{N}-5$ & 005 \\
\hline
\end{tabular}

$\mathrm{S}$ : Susceptible reaction,

$\mathrm{R}:$ Resistant reaction

16) Gilmour, J. (1973). Nature $242: 620$. 
in addition to the above-mentioned 3 varieties, is $1+2+4+40+100+200=347$. Conversely, in the case of race 347 , the number can be decomposed into $1,2,4,40,100$, and 200 , from which we can understand that the race is virulent to those differential varieties, and to those resistance genes having those code numbers.

Some results of inoculation tests with new differentials are presented in Table 1. As shown in the Table, Ken 53-33, an isolate belonging to $\mathrm{T}-1$ race according to the current differentiating procedure, belongs to race 137 in the new system, Ken 60-19 (C-1) to race 037, Ina $72(\mathrm{C}-3)$ to race 031 , and Hoku $1(\mathrm{~N}-1)$ to race 007.

It is desirable that already published results of researches on the distribution and the ecology of races will also be available even after the change of differentiating method. Then, some consideration was taken with arrangement of new differential varieties.

The Gilmour's notation system for races is characterized by triplets of differential varieties. Varieties having singly $P i-k^{s}, P i-a$, and $P i-i$ genes were arranged in the first triplet in the new system. Isolates of $\mathrm{N}$ group races in the current system are virulent only to the differential varieties in the first triplet, with exception such as Ina $168(\mathrm{~N}-4)$. So, $\mathrm{N}$ group races in the current system belong to new races with race number of one figure, 001 to 007 , with a few exception.

For Kanto 51, N group races in the current system are all avirulent, but $\mathrm{C}$ group races are all virulent. All the tested isolates of $\mathrm{T}$ group races in the current system are virulent to Yashiro-mochi $(P i-t a)$, and the tested isolates of $\mathrm{C}$ or $\mathrm{N}$ group races are avirulent to it, with a few exception. In the new system, Kanto 51 was arranged at the top of the second triplet and code number 10 was given for it, and Yashiro-mochi was arranged at the top of the third triplet and code number 100 was given. Therefore, isolates of $\mathrm{C}$ group races in the current system belong to new races with race number of two figures except such cases as Naga $87(\mathrm{C}-3)$, and their tenth digit is odd. Isolates of $\mathrm{T}$ group races in the current system belong to new races with race number of three figures, and their hundredth digit is odd.

In a $168(\mathrm{~N}-4)$ has virulence to Yashiro-mochi, which has the same gene $(P i-t a)$ as one in a line, $K 1$, derived from Tadukan, and belongs to the new race 101 . Tadukan is one of the $\mathrm{T}$ group differentials in the current system, and Ina 168 is avirulent to Tadukan not due to $P i-t a$, but to $P i-a$, so it belongs to race $\mathrm{N}-4$ with the narrowest virulence, in the current differentiating system. In case of Naga 87 , the situation is similar.

The committee wishes to thank Dr. K. Goto, Dr. T. Kozaka, Mr. K. Asaga, Dr. N. Matsuyama, Mr. H. Shimada, Mr. I. Nakanishi and other researchers for providing advice, opinions, and results of inoculation tests. 